\title{
Expressões do (neo)extrativismo: uma leitura sobre a indústria da mineração em Adrianópolis (PR)
}

\author{
Expressions of neo-extractivism: a reading on the mining industry in Adrianópolis, Paraná, \\ Brazil
}

\author{
Rosilene Komarcheski ${ }^{1}$
}

\begin{abstract}
Resumo
O presente estudo tem como objetivo analisar a configuração local que toma o neoextrativismo minerário no município de Adrianópolis-PR. Para tanto, utilizou-se de pesquisa bibliográfica e documental acerca do tema bem como de informações obtidas com a realização de entrevistas abertas com lideranças locais sobre o contexto da mineração na região. A análise se deu a partir das principais características do modelo neoextrativista conforme colocado por autores latinoamericanos em anos recentes, as quais foram complementadas de acordo com os resultados obtidos com a pesquisa para o contexto local. Como resultados principais obteve-se que o município tem se inserido em uma dinâmica neoextrativista, mas que este modelo se expressa de forma específica no local, tendo em vista aspectos socioambientais e político-econômicos que a singulariza diante das dinâmicas mais amplas que tomam o modelo na América Latina em anos recentes.
\end{abstract}

Palavras-chave: Neoextrativismo. Indústria da mineração. Adrianópolis (PR).

\begin{abstract}
The present study aims to analyze the local configuration of the neo-extractivism in the mining industry in Adrianópolis, State of Paraná, Brazil. We used bibliographical and documentary research on the theme and information obtained with open-ended interviews with local leaderships about the mining context of the area. The analysis was based on the main characteristics of the neo-extractivism model as explained by Latin American authors in recent years, which were complemented with results obtained from our local context research. As main results we observed that Adrianópolis is adopting a neo-extractivism dynamics. But this model has specificities in this place, considering socialenvironmental and political-economic aspects that are different compared to broader Latin American dynamics in recent years.
\end{abstract}

Key-words: Neo-extractivism. Mining industry. Adrianópolis. Paraná.

\section{Introdução}

Um dos primeiros atos dos marinheiros portugueses que, a 22 de abril de 1500 , alcançaram a costa sobrecarregada de floresta do continente sul-americano nos 17 graus de latitude sul, foi derrubar uma árvore. Do tronco desse sacrifício ao machado de aço, confeccionaram uma cruz rústica - para eles, o símbolo da salvação da humanidade. (DEAN, 1996, p. 59).

\footnotetext{
1 Doutora em Sociologia (UFPR). Professora adjunta da Universidade Federal de Rondônia. E-mail: rosilenekomarcheski@gmail.com.
} 
A história de nosso continente carrega as marcas desses cinco séculos de exploração de bens naturais, em que por meio principalmente da extração mineral, da exploração madeireira e da implantação de monocultivos agrícolas voltados à exportação ecossistemas inteiros foram devastados. A derrubada daquela árvore, como retrata Warren Dean (1996), marcou simbolicamente o início de um longo período de devastação da natureza na América Latina e, em conjunto, de genocídio, escravização, exploração, expropriação e subalternização de povos indígenas, africanos e afrodescendentes.

A "salvação", que um dia foi representada por uma cruz de madeira, na atualidade se apresenta na figura do "desenvolvimento", enquanto os "salvadores", antes colonizadores europeus, hoje se diluem nas complexas tramas das redes de relações comerciais e políticas nacionais e internacionais que se constituem sob o seu manto. "Desenvolvimento pra que e pra quem?" é um grito de protesto que ecoa com força das vozes de diversos movimentos sociais em anos recentes para questionar e denunciar as finalidades do modelo de desenvolvimento executado no Brasil, o qual tem refundado suas bases em uma política neoextrativista, refletindo-se, assim, em graves ameaças aos territórios e às populações do campo.

O conceito de neoextrativismo vem sendo construído em anos recentes por pesquisadores ligados principalmente às áreas das ciências sociais e ambientais a partir de uma perspectiva crítica para pensar o novo cenário em que se apresentam as atividades extrativistas atualmente na América Latina. Antes de mais nada, cabe ressaltar que o termo extrativismo a que nos referimos aqui diz respeito a atividades extrativas que promovem a extração intensiva de recursos naturais, de forma predatória. Difere radicalmente, portanto, de práticas extrativas realizadas em nível local, de modo autossustentável, por meio das quais comunidades retiram da natureza aquilo de que necessitam sem colocar em risco o ecossistema em que estão inseridos (COELHO; KATO, 2018).

Entre fins do século XX e início do século XXI a América Latina vivenciou um processo de transição de um modelo de acumulação do capital a partir do qual se intensificaram a instalação e a expansão de grandes projetos com vistas à extração, ao controle e à exportação de bens naturais com pouco valor agregado. Esse momento assinalou a inserção de países latino-americanos em uma nova ordem econômica e político-ideológica que emergiu com o boom dos preços internacionais de matérias-primas e bens de consumo, em um contexto de crescente demanda por parte de países centrais e de potências emergentes (SVAMPA, 2013).

A indústria extrativa mineral no Brasil inseriu-se nesse contexto, a partir do qual vivenciou um período de expressivo aumento no número de exportações e dos preços dos minérios, especialmente entre os anos de 2001 e 2010, o que fomentou a expansão de atividades extrativas 
minerárias no país. Esse processo ocorreu no seio do fenômeno chamado "boom das commodities", que teve seu auge entre os anos de 2003 e 2008, fortemente impulsionado pelo "efeito China", que representou o aumento acelerado da demanda por matérias-primas de países asiáticos como China, Coréia do Sul, Índia e Japão (GONÇALVES, 2016).

Tendo em vista esse contexto, no presente estudo buscamos trazer para a discussão o neoextrativismo minerário a partir de um olhar lançado sobre a indústria da mineração no município de Adrianópolis - PR na atualidade, em que atividades ligadas à extração minerária têm sido intensificadas nos últimos anos. O município, situado no lado paranaense da região do Vale do Ribeira, possui 6.376 habitantes, dos quais a maioria, 4.316 (67\%), encontra-se no meio rural (IBGE, 2010), abrigando a maior concentração de Comunidades Remanescentes de Quilombos (comunidades quilombolas) do Paraná, que somam 9 das 38 comunidades já certificadas pela Fundação Cultural Palmares nesse estado (FCP, 2019).

Com uma extensão de 1.349 km² (IBGE, 2010), o território de Adrianópolis é imensamente rico em bens naturais, sendo banhado pelo rio Ribeira de Iguape, contendo em seu subsolo diversos tipos de minerais e abrigando em sua área uma rica biodiversidade. O município encontra-se inserido na área de maior extensão contínua de Mata Atlântica ainda preservada do país, reconhecida como Patrimônio Natural da Humanidade pela Organização das Nações Unidas para a Educação, a Ciência e a Cultura (UNESCO).

Tamanha riqueza tem atraído a atenção de muitos empreendedores ao longo do tempo, que enxergam nos bens naturais da região um potencial de mercantilização e consequente acumulação de capital, o que tem provocado a instalação de empreendimentos extrativistas em Adrianópolis desde meados do século passado. A crescente investida minerária que desponta no município em anos recentes já tem se refletido em diversos danos socioambientais aos territórios e populações locais. Além disso, essa expansão de atividades minerárias representa ainda a existência de uma série de ameaças latentes que podem incidir sobre esses territórios e populações no decorrer dos próximos anos caso o "negócio" da mineração continue a prosperar na região.

Diante disso, o presente estudo traz como objetivo central analisar a configuração atual que toma as atividades ligadas à mineração no município pela perspectiva do neoextrativismo, evidenciando as principais expressões que esse modelo apresenta localmente. Para a consecução do estudo, realizou-se um levantamento bibliográfico acerca do tema e de implicações da atividade minerária em Adrianópolis; uma sistematização de dados oficiais divulgados por instituições públicas referentes à extração minerária e ao financiamento de campanhas eleitorais; e uma pesquisa de campo, realizada entre os anos de 2016 e 2018, por meio da qual foram obtidas informações a partir de 
entrevistas com lideranças locais e com a participação da autora em eventos promovidos por movimentos sociais que contestam a mineração na região. A análise foi realizada com base em uma abordagem teórica sobre neoextrativismo, fundamentada principalmente na caracterização do modelo conforme exposta por Eduardo Gudynas (2014; 2012; 2011; 2009), complementada com abordagens sobre questões mais específicas realizadas por autores como Svampa (2013; 2012), Milanez, Fernandes e Porto (2009) e Oliveira (2014).

O texto que segue está organizado em quatro partes. Primeiramente, é apresentada uma discussão teórica sobre o neoextrativismo, em que se busca destacar suas características centrais e as principais expressões que esse modelo reflete em anos recentes na América Latina. Depois, é realizada uma contextualização das atividades ligadas à indústria da mineração em Adrianópolis na atualidade, por meio da qual são evidenciados o perfil da atividade, os principais tipos de minérios extraídos ou para os quais existem concessões de exploração ativas no município e os respectivos empreendimentos que possuem essas concessões de exploração minerária. Na sequência, efetua-se uma análise sobre a configuração atual do neoextrativismo no município, tendo como base o modelo proposto por Gudynas $(2014 ; 2012 ; 2011 ; 2009)$, a partir do qual são evidenciadas algumas das principais expressões que esse modelo apresenta localmente. Por fim, encerra-se o texto com alguns apontamentos a título de conclusão sobre o problema de estudo, sendo enfatizadas especificidades que o modelo neoextrativista apresenta no local.

\section{(Neo)extrativismo}

Para Alberto Acosta (2016), o extrativismo, que carrega uma herança colonial forjada há mais de 500 anos, é uma modalidade de acumulação do capital por meio da qual são removidas grandes quantidades de recursos naturais, os quais, não processados ou pouco processados, são destinados principalmente à exportação. Logo, o neoextrativismo, como o próprio termo sugere, é compreendido como uma versão contemporânea do extrativismo, que tem se configurado como um componente fundamental do atual modelo de desenvolvimento promovido em diversos países da América Latina em anos recentes (ACOSTA, 2016; GUDYNAS, 2011; SVAMPA, 2013).

As principais características deste modelo são: a extração intensiva de recursos naturais direcionados principalmente à exportação de matérias primas, em grande parte não renováveis, com pouco ou nenhum processamento; a inserção subordinada de países latinoamericanos no mercado 
internacional; uma maior presença do Estado nestas atividades; e a geração e o aprofundamento de impactos e conflitos socioambientais (GUDYNAS, 2014; 2012; 2011; 2009).

As atividades convencionais de extrativismo incluem os setores do petróleo, do gás e da mineração, mas também se inserem no modelo neoextrativista grandes empreendimentos de monocultivos agrícolas e de exploração madeireira e pesqueira (ACOSTA, 2016). As obras de infraestrutura executadas para viabilizar a extração e exportação das demais atividades, seja no setor dos transportes (rodovias, ferrovias, hidrovias, portos, etc.), da geração de energia (centrais hidroelétricas e barragens) ou da comunicação, ainda podem ser consideradas como integrantes deste modelo, como sugerem Gudynas (2009; 2011) e Svampa (2013). No caso específico da mineração, o extrativismo inclui atividades referentes à localização, à prospecção, à extração e ao processamento de minérios para a sua utilização industrial (COELHO; KATO, 2018).

O modelo neoextrativista tem conduzido a economia latinoamericana a um processo de reprimarização, com a expansão de grandes empreendimentos que promovem o controle, a extração e a exportação de bens naturais, caracterizando o que Svampa (2013) intitula de "consenso de los commodities". Tal processo acaba promovendo a inserção de países latinoamericanos no mercado global de maneira subordinada, uma vez que, ao alimentar o crescimento econômico interno às custas da exportação de matéria prima, respondendo a crescentes demandas de países centrais e potências emergentes, produz novas assimetrias entre países do Norte e do Sul global e gera novos conflitos socioambientais (GUDYNAS, 2011; SVAMPA, 2013).

O Estado passa a assumir um papel mais ativo no modelo neoextrativista, efetuando intervenções diretas e indiretas, seja por meio da criação e expansão de empresas extrativistas estatais ou via concessão de subsídios, financiamentos e apoios em infraestrutura oferecidos pelas diversas esferas de governo a empresas privadas do setor (GUDYNAS, 2012; 2011; 2009). Exemplo deste papel desempenhado pelo Estado no caso brasileiro é a regulamentação do setor minerário inscrita no novo Código da Mineração (Lei n ${ }^{\circ}$ 13.575/2017), no qual é possível verificar uma íntima correlação entre seus principais objetivos e as características do neoextrativismo, conforme aponta estudo realizado por Milanez e Santos (2013).

Uma particularidade que se apresenta nas principais discussões acerca do neoextrativismo na atualidade diz respeito à forma de atuação dos governos progressistas na América Latina em relação às atividades extrativistas, principalmente a partir do ano 2000. Estes governos progressistas, de modo geral, de acordo com Acosta (2016), Gudynas (2009; 2011; 2012) e Svampa (2013), teriam dado continuidade ao modelo extrativista tradicional, praticado por governos conservadores anteriores, contudo, sob as suas gestões o Estado estaria assumindo um caráter mais compensador, 
onde a tributação de atividades extrativistas pode gerar algum retorno social à população por meio da execução de políticas redistributivas de combate à pobreza ${ }^{2}$. Paradoxalmente, este caráter compensador do Estado acaba contribuindo para a promoção de uma aparente aceitação pública de atividades que causam grandes impactos ambientais, sociais e culturais, invisibilizando e silenciando assim muitos conflitos por elas desencadeados.

Ao analisar o caso brasileiro, especificamente, Gonçalves, Milanez e Wanderley (2018) apontam que o governo liberal-conservador, representado pelo presidente Michel Temer (2016-2018, PMDB), que deu sequência à gestão do governo progressista de Dilma Vana Roussef (2010-2016, PT), manteve um posicionamento favorável à expansão de atividades extrativistas no país, assim como o governo que lhe precedeu. Contudo, na nova gestão, a renda mineral obtida com estas atividades deixa de ser alvo de políticas redistributivas e passa a ser orientada pelas forças do mercado, sendo transferida ao setor financeiro, por meio do pagamento de serviços da dívida pública. Desse modo, verifica-se em anos recentes no Brasil uma mudança no perfil do modelo neoextrativista, o qual passa de um "neoextrativismo progressista" a um "neoextrativismo liberal-conservador" (GONÇALVES; MILANEZ; WANDERLEY, 2018).

Independentemente do caráter progressista ou liberal-conservador que toma o neoextrativismo no país, os impactos ambientais, sociais e culturais gerados com a instalação e operação de empreendimentos extrativistas permanecem. Dentre estes, destacam-se os seguintes: a contaminação do solo e das águas; a poluição atmosférica; o desmatamento e a perda de biodiversidade; a violência física e simbólica contra populações atingidas e lideranças locais que se opõe aos empreendimentos; e a fragmentação territorial e desterritorialização de territórios tradicionais, dentre outros (GUDYNAS, 2011).

Svampa (2013) ressalta o caráter perverso que o modelo neoextrativista adquire na sua materialidade local, ao promover impactos significativos nos territórios onde se instalam seus empreendimentos e sobre as populações que neles habitam:

El neoextractivismo instala una dinámica vertical que irrumpe en los territorios y a su paso va desestructurando economías regionales, destruyendo biodiversidad y profundizando de modo peligroso el proceso de acaparamiento de tierras, al expulsar o desplazar a comunidades rurales, campesinas o indígenas, y violentando procesos de decisión ciudadana (SVAMPA, 2013, p. 34).

\footnotetext{
${ }^{2}$ Um exemplo de compensação, no caso brasileiro, é a Lei no 12.858 (BRASIL, 2013), que previa que parte dos royalties arrecadados com a exploração de petróleo e gás natural do pré-sal fossem destinados aos setores da saúde e da educação públicas.
} 
Os impactos gerados com o avanço do neoextrativismo sobre populações camponesas, tradicionais e indígenas têm desencadeado uma série de conflitos socioambientais em territórios onde são instalados tais empreendimentos e nas suas respectivas áreas de influência. Desse modo, os empreendimentos nem sempre são recebidos de forma passiva pela população local, tendo sido cada vez mais frequentes os casos em que grupos atingidos e ameaçados se manifestam contrários e reagem aos danos e ameaças sofridos. Svampa (2012) aponta que esta nova inflexão extrativista pela qual passa a América Latina tem levado a uma explosão de conflitos socioambientais, que são explicitados nas lutas em defesa da terra travadas por populações camponesas e indígenas e na emergência de novas formas de mobilização e participação cidadã centradas nos bens naturais.

\section{A indústria da mineração em Adrianópolis - PR}

O extrativismo, que atravessa a história da América Latina desde os idos de 1500, deixou profundas cicatrizes no Vale do Ribeira. Uma das primeiras a sofrer a colonização europeia na primeira metade do século $\mathrm{XVI}^{3}$, a região foi intensamente marcada pela exploração de bens naturais e pela violência a ela adjacente a povos indígenas, africanos e afrodescendentes. Em fins do século XVI e início do século XVII, as bandeiras da mineração subiam o rio Ribeira em busca de ouro, fundavam cidades (como Iporanga, Jacupiranga e Xiririca - atualmente Eldorado) e escravizavam a população africana e afrodescendente.

A intensa exploração aurífera que ocorreu no Vale do Ribeira levou o minério à quase extinção em meados do século XIX, quando latifúndios instalados na região passaram a desenvolver a monocultura de arroz, principalmente, utilizando ainda a mão de obra escravizada. Em 1832 tem-se o registro da descoberta das primeiras jazidas de minério de chumbo na região, no município de Iporanga (SP), e em 1919 a primeira jazida foi explorada com fins comerciais, sendo o minério exportado para a Espanha (PAIVA, 1929; LEONARDOS, 1934 apud SILVA, 1997). Desde então, a exploração se intensificou na região, sendo que até 1954 toda a produção de minério de chumbo do país saía das minas do Vale do Ribeira (DAITX, 1985b apud SILVA, 1997).

Adrianópolis, assim como o Vale do Ribeira de modo geral, parece carregar o carma colonial do extrativismo, especialmente o minerário. O município foi palco da intensa exploração de minério de chumbo, principalmente entre os anos de 1954 e 1995, período em que operou no local a empresa

\footnotetext{
${ }^{3}$ Em 1531 colonizadores europeus fundaram a cidade de Cananéia, atualmente situada no litoral sul do estado de São Paulo.
} 
Plumbum S/A, a qual refinava todo o minério extraído na região, além de atuar na extração e refino de outros minérios, como ouro e prata, por exemplo. A exploração e o refino do minério de chumbo deixaram como legado graves danos à natureza e à saúde da população local que perduram até os dias atuais. Exemplos disso são os passivos ambientais deixados pelas atividades da Plumbum, que implicaram contaminação do solo e das águas por elevados níveis de chumbo e de arsênio na área do entorno da fábrica. Estudos realizados nas comunidades próximas de Vila Mota e Capelinha, localizadas no município, indicam que um expressivo número de moradores locais possui ainda hoje elevados níveis de chumbo na corrente sanguínea e que o metal se encontra presente também em outras espécies animais e vegetais da região, incluindo alimentos cultivados por moradores (CUNHA et al., 2006). Cabe mencionar que o próprio encerramento das atividades dessa empresa na região se relaciona intimamente à magnitude dos impactos socioambientais causados por ela, o que foi largamente denunciado no país ${ }^{4}$.

Adrianópolis possui um subsolo bastante rico em abundância e diversidade de minerais, o que tem atraído a atenção de muitos investidores do setor minerário em anos recentes. Nesse cenário, empresas mineradoras, interessados em desenvolver atividades ligadas à mineração e investidores em geral têm adquirido um número crescente de concessões de exploração de minérios no município, especialmente nas últimas duas décadas. De acordo com dados disponibilizados pela Agência Nacional de Mineração (ANM, 2018), atualizados em abril de 2018, havia no período 119 processos minerários ativos em Adrianópolis referentes a diversas substâncias, dentre os quais se encontravam desde processos de minas já em operação até requerimentos de pesquisa para exploração em processo de avaliação pela $\mathrm{ANM}^{5}$.

Os 119 processos minerários ativos em Adrianópolis somados correspondem a uma área total de cerca de 70 mil ha, de acordo com dados disponibilizados pela ANM (2018). Apesar de existirem algumas sobreposições de áreas com concessões de minérios de diferentes tipos, a soma total dessas áreas denota o potencial da magnitude espacial desta atividade extrativista na região, visto que equivale a mais da metade da área total do município, que é de 134.900 ha $\left(1.349 \mathrm{~km}^{2}\right.$ ) (IBGE, 2010). Nos processos minerários em questão encontram-se listados 18 diferentes tipos de minérios, conforme ilustrado no Quadro 1, para os quais é requerida a pesquisa ou a lavra, de acordo com a fase

\footnotetext{
${ }^{4}$ A Plumbum possuía duas instalações de refino de chumbo no país quando encerrou suas atividades, na década de 1990 , sendo uma em Adrianópolis e outra em Santo Amaro da Purificação, na Bahia. Em Santo Amaro a Plumbum também causou graves impactos socioambientais, o que foi denunciado nacionalmente inclusive por uma música, chamada "Purificar o Subaé", composta por Caetano Veloso, natural do município. (CARTA CAPITAL, 2012).

5 As etapas pelas quais um processo minerário ativo deve passar até que o requerente possa efetivamente explorar o minério são as seguintes: requerimento de pesquisa, autorização de pesquisa, requerimento de lavra e concessão de lavra (ANM, 2018).
} 
em que se encontra cada processo.

QUADRO 1 - TIPOS DE MINÉRIOS E NÚMERO DE PROCESSOS MINERÁRIOS ATIVOS

\begin{tabular}{|l|l|l|l|l|l|}
\hline \multicolumn{7}{|c|}{ Tipos de minérios/No de processos } \\
\hline Calcário & 38 & Areia & 7 & Argila & 2 \\
\hline Calcário calcítico & 23 & Ouro & 5 & Cascalho & 2 \\
\hline Chumbo & 23 & Fluorita & 4 & Caulim & 1 \\
\hline Zinco & 21 & Filito & 4 & Fosfato & 1 \\
\hline Cobre & 15 & Prata & 4 & Granito & 1 \\
\hline Dolomito & 9 & Quartzito & 3 & Mármore & 1 \\
\hline \multicolumn{7}{|c|}{ Número total de substâncias: 18 } \\
\hline
\end{tabular}

FONTE: Elaborado pela autora com base em dados disponibilizados pela ANM (2018), referentes ao mês de abril de 2018.

LEGENDA: Cada processo minerário pode conter o requerimento para pesquisa e lavra de mais de um tipo de minério, motivo pelo qual a soma do número de processos nos quais aparecem cada tipo de minério (163) ultrapassa o total de 119, quantidade total de processos.

A partir dos dados apontados acima, verifica-se que os minérios que aparecem em um maior número de processos (mais de 10 por substância) são, respectivamente: o calcário (38 processos), o calcário calcítico (23 processos), o chumbo (23 processos), o zinco (21 processos) e o cobre (15 processos). Contudo, apesar de haverem processos registrados referentes a 18 tipos diferentes de minérios em Adrianópolis, apenas 3 substâncias estão sendo efetivamente exploradas atualmente no município, ao menos desde o ano de 2009, que são o calcário, o calcário calcítico e a areia. Esta informação pode ser verificada a partir dos dados sobre a arrecadação do imposto chamado Compensação Financeira pela Exploração dos Recursos Minerais (CFEM) ${ }^{6}$ no município de Adrianópolis entre os anos de 2009 e 2017, disponibilizados pela ANM (2018), conforme ilustrado no Quadro 2.

QUADRO 2 - ARRECADAÇÃO DE CFEM POR SUBSTÂNCIA EM ADRIANÓPOLIS 2009-2017

\begin{tabular}{|c|c|c|c|}
\hline Ano & $\begin{array}{c}\text { Arrecadação } \\
\text { total CFEM (R\$) }\end{array}$ & Substância & $\begin{array}{c}\text { Valor arrecadado } \\
\text { por substância }(\mathbf{R} \$)\end{array}$ \\
\hline \multirow{3}{*}{2017} & \multirow{3}{*}{$880.563,20$} & Areia & $1.470,68$ \\
\hline & & Calcário & $4.185,00$ \\
\hline & & Calcário calcítico & $874.907,52$ \\
\hline \multirow[t]{2}{*}{2016} & \multirow[t]{2}{*}{$847.797,33$} & Areia & $11.994,40$ \\
\hline & & Calcário calcítico & $835.802,93$ \\
\hline \multirow[t]{2}{*}{2015} & \multirow[t]{2}{*}{$281.976,69$} & Areia & $15.151,89$ \\
\hline & & Calcário calcítico & $266.824,80$ \\
\hline \multirow[t]{2}{*}{2014} & \multirow[t]{2}{*}{$125.513,05$} & Areia & $5.790,20$ \\
\hline & & Calcário calcítico & $119.722,85$ \\
\hline \multirow[t]{2}{*}{2013} & \multirow[t]{2}{*}{$175.543,26$} & Areia & 615,97 \\
\hline & & Calcário calcítico & $174.927,29$ \\
\hline \multirow[t]{2}{*}{2012} & \multirow[t]{2}{*}{$77.215,07$} & Calcário & $28.189,94$ \\
\hline & & Calcário calcítico & $49.025,13$ \\
\hline \multirow[t]{2}{*}{2011} & $85.190,28$ & Calcário & $5.966,71$ \\
\hline & & Calcário calcítico & $79.223,57$ \\
\hline 2010 & $92.209,48$ & Calcário calcítico & $92.209,48$ \\
\hline 2009 & $18.336,31$ & Calcário calcítico & $18.336,31$ \\
\hline
\end{tabular}

FONTE: Elaborado pela autora, com base em dados disponibilizados pela ANM (2018).

LEGENDA: A ANM disponibilizou em sua página virtual apenas dados referentes à exploração minerária a partir do ano de 2009 e os dados disponibilizados referentes ao ano de 2018 encontravam-se incompletos no momento da realização desta pesquisa, motivo pelo qual os dados contidos no quadro se referem aos anos incluídos no intervalo de tempo que vai de 2009 a 2017.

\footnotetext{
${ }^{6} \mathrm{~A}$ arrecadação do CFEM ocorre por meio da ANM, sendo que o seu pagamento é de responsabilidade de toda e qualquer pessoa física ou jurídica que realize a extração e comercialização ou uso de minérios no território nacional.
} 
De acordo com os dados acima, observa-se que desde o ano de 2009 vem ocorrendo um crescimento significativo no valor de CFEM arrecadado em Adrianópolis, o que indica também o proporcional aumento expressivo na exploração dos minérios em questão, principalmente de calcário calcítico. Dados disponibilizados pela ANM (2018) apontam que o município de Adrianópolis ficou na quarta posição no ranking de arrecadação de CFEM no estado do Paraná no ano de 2017, com $\mathrm{R} \$ 880.563,20$, tendo ficado atrás apenas da arrecadação realizada nos municípios de Campo Largo $(\mathrm{R} \$ 1.024 .292,68)$, Figueira ( $\mathrm{R} \$ 1.556 .220,39)$ e Rio Branco do Sul ( $\mathrm{R}$ \$ 2.565.265,70), o que indica a expressividade da extração minerária realizada no município em nível estadual.

O grande número de processos minerários ativos referentes ao calcário e ao calcário calcítico se relacionam diretamente ao significativo aumento da exploração desses minérios para a produção de cimento em anos recentes no município. As atividades da fábrica Supremo Secil Cimentos, antiga Companhia Margem Mineração, em operação em Adrianópolis desde 2015, têm acentuado significativamente a demanda por esses minérios. Além disso, há o interesse de outras empresas do setor na exploração do calcário, o que se relaciona também com a intenção de instalação de outras fábricas de cimento no município, como é o caso das empresas Tupi, Golden Mix e Companhia Vale do Ribeira (GAZETA DO POVO, 2014).

As empresas Tupi e Golden Mix inclusive chegaram a concluir os Estudos de Impacto Ambiental e Relatórios de Impacto Ambiental (EIA/RIMA) para a instalação de suas fábricas no município, respectivamente, nos anos de 2012 e 2014, conforme consta na página virtual do Instituto Ambiental do Paraná (IAP, 2018). No entanto, até o presente momento essas empresas ainda não realizaram suas instalações, mesmo caso em que se encontra a Companhia Vale do Ribeira, que também ainda não efetuou a instalação de sua fábrica.

Outro dado que chama a atenção é o grande número de processos minerários ativos em Adrianópolis referentes a substâncias metálicas, principalmente de chumbo, zinco e cobre, que, juntas, aparecem em 59 processos, sendo que a maioria deles (35) é relativamente recente, tendo sido abertos a partir do ano 2000, conforme apontam dados disponibilizados pela ANM (2018). A extração minerária dessas substâncias não tem sido realizada no município atualmente, no entanto, o fato de haver processos ativos referentes a elas indica que, ao menos, existe uma expectativa por parte dos requerentes de que estas substâncias venham a ser exploradas.

Os 119 processos minerários registrados na ANM foram abertos por 31 diferentes requerentes, sendo que destes 26 são pessoas jurídicas (empresas) e 5 são pessoas físicas, como apontado no Quadro 3. 


\section{QUADRO 3 - REQUERENTES DOS PROCESSOS MINERÁRIOS ATIVOS}

\begin{tabular}{|l|l|}
\hline \multicolumn{1}{|c|}{ Requerentes dos processos } & $\begin{array}{c}\mathbf{N}^{\mathbf{0}} \text { de } \\
\text { processos }\end{array}$ \\
\hline Grupo Votorantim* & 47 \\
\hline Compacta Mineradora & 10 \\
\hline Geminas Mineradora Ltda & 5 \\
\hline Plumbum do Brasil Ltda & 5 \\
\hline Tupi Mineradora de Calcário Ltda & 4 \\
\hline Cbe Companhia Brasileira de Equipamento & 3 \\
\hline Itaoeste Serviços e Participações Ltda & 3 \\
\hline Sandra Mineração Ltda & 3 \\
\hline Arauco Forest Brasil AS & 2 \\
\hline Cachoeira Metais Ltda & 2 \\
\hline Conbase Mineradora Ltda & 2 \\
\hline Golden Mix Construções e Incorporações Ltda & 2 \\
\hline Margem Companhia de Mineração & 2 \\
\hline Mina Mineração Adrianópolis SA & 2 \\
\hline Empresas com apenas 1 processo cada & $\mathbf{9}$ \\
\hline Processos de pessoas físicas (5 pessoas no total) & $\mathbf{1 8}$ \\
\hline Número total de processos minerários & $\mathbf{1 1 9}$ \\
\hline
\end{tabular}

FONTE: Elaborado pela autora, com base em dados disponibilizados pela ANM (2018) referentes ao mês de abril de 2018. LEGENDA: Cada processo minerário pode conter o requerimento para a pesquisa e lavra de mais de um tipo de minério.

* Com o "Grupo Votorantim" nos referimos aqui ao conjunto formado por 4 empresas pertencentes ao mesmo grupo que possuem concessões minerárias no município, que são: Votorantim Cimentos SA, Votorantim Cimentos Brasil SA, Votorantim Metais Zinco SA e Companhia Brasileira de Alumínio.

Em relação às empresas requerentes dos processos citados é relevante observar o expressivo número de processos ativos abertos em nome de empresas pertencentes ao Grupo Votorantim, como chamamos aqui, o qual inclui a Votorantim Cimentos SA, a Votorantim Cimentos Brasil SA, a Votorantim Metais Zinco SA e a Companhia Brasileira de Alumínio (CBA), que juntas acumulam um total de 47 processos minerários ativos. A maioria destes processos são referentes às substâncias calcário, dolomito, cobre, zinco, chumbo e fluorita, de acordo com dados disponibilizados pela ANM (2018). Outro dado que desperta a atenção acerca dos requerentes é a existência de processos ativos em nome da Arauco Forest Brasil SA, uma empresa do setor florestal-madeireiro, que possui 2 processos referentes à exploração de calcário, cascalho, caulim e saibro no município, segundo dados disponibilizados pela ANM (2018).

O conjunto de dados apresentados acima evidencia o cenário extrativista no qual se encontra Adrianópolis na atualidade. Este cenário denota a perspectiva futura de expansão de atividades ligadas ao setor da mineração, tendo em vista a expectativa de instalação de novos empreendimentos, como as fábricas de cimento, por exemplo, e o grande número de processos minerários ativos referentes a substâncias que ainda não estão sendo exploradas no município, como é o caso do cobre, do zinco e do chumbo. Desse modo, os dados referentes aos processos minerários ativos em Adrianópolis indicam mais do que a existência de extração minerária efetiva até o momento, também a possibilidade de que as atividades extrativistas venham a crescer substancialmente nos próximos 
anos, o que implica no risco do desencadeamento de uma série de consequências, algumas ainda imprevisíveis.

\section{Configuração local do neoextrativismo minerário}

Apesar de o modelo neoextrativista apresentar características gerais, que podem ser verificadas, por exemplo, em diferentes países da América Latina, a sua materialidade se expressa de modo específico nos territórios onde são desenvolvidas as atividades ligadas ao setor da mineração. Nesse sentido, Coelho e Kato (2018) afirmam que:

A materialidade do extrativismo é local, mas suas formas de organização social e econômica são diretamente relacionadas às dinâmicas globais, o que desequilibra as relações entre as empresas e as comunidades locais e, ainda, diminui a capacidade estatal de regulação, licenciamento e fiscalização dos projetos extrativistas (COELHO e KATO, 2018, p. 114).

Tendo em vista o conjunto destas dinâmicas mais gerais e específicas sob as quais se apresenta o modelo neoextrativista localmente, analisamos na sequência a configuração atual que este modelo apresenta no município de Adrianópolis, tendo como base as principais características do neoextrativismo enunciadas por Gudynas (2014; 2012; 2011; 2009), conforme apontamos anteriormente, às quais somamos algumas contribuições de outras(os) autoras(es) para podermos contemplar a análise acerca das especificidades locais que este modelo expressa.

\section{a) Extração intensiva de recursos naturais direcionados principalmente à exportação de matérias}

\section{primas, com pouco ou nenhum processamento}

Em Adrianópolis, como já evidenciado, vem ocorrendo a extração intensiva de minérios, principalmente de calcário para a produção de cimento, este que é considerado no mercado global como uma commodity mineral. No entanto, esses recursos extraídos no município não têm sido destinados à exportação, ao menos por enquanto, uma vez que a grande demanda por cimento do mercado interno brasileiro em anos recentes tem absorvido basicamente toda a produção nacional, de acordo com informações divulgadas pela organização não governamental Cimento.org (2018). Na atualidade, a produção de cimento realizada pela Supremo Secil em Adrianópolis, por exemplo, tem como destino principal alimentar os mercados dos estados da região Sul e de São Paulo (CASA CIVIL DO ESTADO DO PARANÁ, 2015).

Além disso, o expressivo número de processos minerários ativos referentes a outras 
substâncias minerais, além do calcário, denota o interesse dos seus requerentes na extração e comercialização destas. Nesse sentido, cabe uma atenção especial em relação aos minerais metálicos, como o cobre, o chumbo e o zinco, os quais também são considerados commodities no mercado global e são minérios que têm sido efetivamente exportados pelo Brasil em anos recentes, segundo dados do Instituto Brasileiro de Mineração (IBRAM, 2015). Desse modo, a exploração desses minérios em Adrianópolis, que se encontra em estado de latência, se e quando se efetivar, pode vir a gerar a sua exportação, acentuando, assim, o cenário neoextrativista local.

\section{b) Inserção subordinada no mercado internacional}

Mesmo não ocorrendo a exportação de minérios a partir da exploração minerária em Adrianópolis na atualidade, é possível observar algumas relações que apontam para um tipo de subordinação, mesmo que indireta, ao mercado internacional. Esta situação pode ser percebida, por exemplo, a partir do notável interesse na instalação de empreendimentos minerários de propriedade estrangeira no município. Este é o caso da fábrica de cimentos Supremo-Sécil, que pertence ao grupo português Sécil, o qual, por sua vez, pertence ao grupo SEMAPA, também de origem portuguesa. Caso semelhante se verifica com a Companhia Vale do Ribeira, empresa constituída em sociedade entre o grupo Trevo, proprietário da antiga Plumbum, de origem nacional, e a Citic HIC (Heavy Industries Corporation), uma grande empresa chinesa, fornecedora de equipamentos para a indústria cimenteira. Outro caso é o da Arauco Forest Brasil, subsidiária do grupo chileno Celulosa Arauco, que, apesar de atuar no setor madeireiro, possui concessões minerárias em Adrianópolis, conforme ilustrado nos dados acima.

Assim, mesmo que sem necessariamente realizar a exportação de commodities, o fato de haverem grandes empresas estrangeiras atuando ou que pretendem atuar no setor da mineração em Adrianópolis acaba contribuindo para um tipo de subordinação ao mercado internacional a partir da exploração de recursos naturais, uma vez que o patrimônio constituído e o lucro gerado por estes empreendimentos acabam não ficando no país. Ao lado disso tem-se que os recursos naturais minerais explorados, que se encontram no território nacional e, no caso dos minérios, são de propriedade do Estado que concede a sua exploração às empresas, vão alimentar o acúmulo de capital estrangeiro em detrimento do nacional.

\section{c) Presença do Estado em atividades ligadas à mineração}

De acordo com informações da organização Cimento.org (2018), entre os anos de 2005 e 2014 o mercado cimenteiro nacional viveu um período de notável crescimento na comercialização do 
cimento, vindo a sofrer quedas a partir de 2015. A organização afirma também que o crescimento do mercado de cimento naquele período se relaciona intimamente com o crescimento de emprego e renda no país, com a expansão do crédito imobiliário e com as obras de infraestrutura executadas por meio do Plano de Aceleração do Crescimento (PAC), o que aumentou significativamente a demanda nacional pelo produto (CIMENTO.ORG, 2018).

Nesse sentido, cabe ressaltar a participação, mesmo que indireta, do governo federal no estímulo ofertado ao mercado cimenteiro, atrelado ao da construção civil, o que se refletiu na exploração minerária em diversas regiões do país, assim como em Adrianópolis. Isso se deu especialmente durante parte das duas gestões do presidente Luiz Inácio Lula da Silva (PT) e, ao menos, da primeira gestão da presidenta Dilma Vana Rousseff (PT), considerando ainda que os fatores que levaram ao crescimento do mercado cimenteiro elencados acima se desenvolveram principalmente sob políticas promovidas durante suas gestões. Além disso, parte dos recursos financeiros arrecadados com a cobrança de impostos sobre a produção minerária nesse período teve como destino o financiamento de políticas sociais, como aponta Gudynas (2009; 2011), o que, segundo o autor, teria sido uma justificativa para o incentivo de governos progressistas a atividades extrativistas na América Latina.

Em nível estadual, a participação do Estado pode ser verificada principalmente a partir dos incentivos fiscais oferecidos pelo governo do estado do Paraná para a construção de fábricas de cimento em Adrianópolis. Merece destaque, nesse sentido, o Programa Paraná Competitivo, que tinha como objetivo fornecer a concessão de incentivos fiscais a grupos empresariais nacionais e estrangeiros que se pretendiam instalar-se no estado, programa este promovido sob a gestão do exgovernador Carlos Alberto Richa (PSDB) (AEN, 2011). De acordo com informações divulgadas na página virtual da Casa Civil do Estado do Paraná (2015), a empresa Supremo-Sécil contou com incentivos fiscais e outros benefícios para viabilizar a instalação de sua unidade fabril em Adrianópolis, por meio de um acordo firmado com o governo estadual via Programa Paraná Competitivo $^{7}$. De igual maneira, as empresas Tupi, Golden Mix e Companhia Vale do Ribeira também chegaram a ter acordos negociados com o governo estadual por meio deste mesmo programa para a instalação de outras três fábricas de cimento no município, segundo informações da Agência Estadual de Notícias do Paraná (AEN, 2014), ainda que a instalação de suas unidades não tenha se concretizado até o presente momento.

Os estímulos à instalação destes empreendimentos se deram também em nível municipal,

\footnotetext{
${ }^{7}$ Segundo informações divulgadas pelo jornal Gazeta do Povo (06/04/2014), por meio do Programa Paraná Competitivo, a Supremo ficaria oito anos recolhendo apenas uma fatia do Imposto sobre Circulação de Mercadorias e Serviços (ICMS) que seria arrecadado com as atividades da indústria.
} 
tendo em vista que a prefeitura de Adrianópolis participou de acordos firmados entre o governo estadual e representantes das empresas citadas para a instalação dos respectivos empreendimentos. O apoio dado à instalação destes empreendimentos, neste caso, foi explicitado em discurso proferido pelo prefeito do município à época, João Manoel Pampanini (PT), no contexto da inauguração da fábrica de cimentos Margem (atual Supremo Sécil), quem alegou que Adrianópolis teria uma "grande parceria com o estado" para levar investimentos para a região, fazendo alusão aos acordos firmados com esta empresa por meio do Programa Paraná Competitivo (CASA CIVIL DO ESTADO DO PARANÁ, 2015). Ainda, segundo ele, o funcionamento da fábrica seria "a garantia de um futuro promissor para Adrianópolis" (CASA CIVIL DO ESTADO DO PARANÁ, 2015).

\section{d) Financiamento de campanhas eleitorais por empresas extrativistas minerárias}

Estreitamente relacionadas com a atuação de representantes do poder público em incentivos oferecidos à instalação de empreendimentos extrativistas minerários no município encontram-se relações existentes entre candidaturas ao pleito de prefeito de Adrianópolis e empresas do setor da mineração durante as campanhas eleitorais de 2008 e 2012, como pode ser observado no Quadro 4. No ano de 2008 a Companhia Brasileira de Alumínio (CBA), pertencente ao Grupo Votorantim, participou como doadora de recursos financeiros para as campanhas de dois candidatos, um do Partido Progressista (PP) e outro do Partido dos Trabalhadores (PT). Já nas eleições municipais de 2012 a Votorantim foi doadora da campanha de um candidato, do Partido da Social Democracia Brasileira (PSDB), enquanto que a Margem efetuou doações a dois candidatos, um do PSDB e outro do PT.

QUADRO 4 - DOAÇÕES DE CAMPANHA REALIZADAS POR EMPRSAS LIGADAS AO SETOR DA
MINERAÇÃO A CANDIDATOS A PREFEITO DE ADRIANÓPOLIS EM 2008 E 2012

\begin{tabular}{|c|c|c|c|c|c|}
\hline Ano & Candidato(a) & Partido & $\begin{array}{c}\text { Receita } \\
(\mathbf{R} \$)^{*}\end{array}$ & Doador & $\begin{array}{l}\text { Valor } \\
(\mathbf{R} \$)^{* * *}\end{array}$ \\
\hline \multirow[t]{3}{*}{2012} & João Manoel Pampanini**** & PT & $107.238,15$ & Margem & 5.000 \\
\hline & \multirow[t]{2}{*}{ Sidival Bacil de Souza } & \multirow[t]{2}{*}{ PSDB } & \multirow[t]{2}{*}{$52.979,86$} & Margem & 5.000 \\
\hline & & & & Votorantim & 25.000 \\
\hline \multirow[t]{5}{*}{2008} & Celso Maciel Diniz & PPS & ------ & NR & ------ \\
\hline & Eliane G. A. M. de Oliveira & $\mathrm{PP}$ & $36.451,84$ & $\mathrm{CBA}$ & 7.000 \\
\hline & João Manoel Pampanini*** & PT & $30.542,22$ & $\mathrm{CBA}$ & 7.000 \\
\hline & Osmar Maia & PMDB & $26.602,15$ & NR & $\begin{array}{ll}----- \\
\end{array}$ \\
\hline & Sidival Bacil de Souza & DEM & 17.592 & NR & 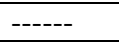 \\
\hline
\end{tabular}

FONTE: Elaborado pela autora, com base em dados disponibilizados pelo Tribunal Superior Eleitoral (TSE, 2018). LEGENDA:

CBA: Companhia Brasileira de Alumínio, pertencente ao Grupo Votorantim.

Margem: atual Supremo-Sécil Cimentos.

NR: não recebeu doação de empresa ligada ao setor da mineração.

* Receita total acumulada na campanha por cada candidato.

**Valor doado por cada empresa aos respectivos candidatos.

$* * *$ Candidato eleito. 
O financiamento de campanhas realizado por empresas do setor da mineração a candidatos em Adrianópolis coincide com o interesse dessas empresas na instalação de empreendimentos no município nos períodos indicados. A CBA, por exemplo, tinha interesse na execução do projeto de construção da usina hidrelétrica (UHE) Tijuco Alto, de sua propriedade, o qual atingiria vários municípios do Vale do Ribeira, dentre eles Adrianópolis, o que acabou não se concretizando ${ }^{8}$. A Votorantim, por sua vez, acenou o interesse na instalação de uma fábrica de cimento no município, o que chegou a ser noticiado em 2014 (GAZETA DO POVO, 2014), mas que também não se realizou até o presente momento. A Margem inaugurou sua fábrica de cimento em Adrianópolis em 2015, como já mencionado.

A esse respeito, cabem ao menos duas observações relevantes. Uma primeira é que o prefeito eleito nas duas eleições citadas, João Manoel Pampanini, recebeu financiamento de empresas do setor minerário em suas campanhas, sendo em 2008 da CBA e em 2012 da Margem. Outra observação que pode ser feita a partir dos dados apontados no Quadro 4 é que nessas duas eleições duas empresas efetuaram doações concomitantes a campanhas de candidatos de partidos diferentes, sendo que em 2008 a CBA fez doações a um candidato do PP e outro do PT e em 2012 a Margem doou recursos financeiros a um candidato do PSDB e outro do PT. Diante disso, pode-se constatar que as doações a campanhas realizadas por ambas empresas não possuem diretamente um caráter político-ideológico, denotando uma intenção implícita por parte dessas empresas em obter algum tipo de apoio político-econômico futuro dos candidatos que fossem eleitos, independentemente de seus partidos de origem.

Uma dinâmica semelhante a essa foi percebida por Oliveira (2014), mas em nível federal, que ao analisar o financiamento de campanhas por empresas do setor da mineração nas eleições de 2014, concluiu que essas empresas possuem um grande poder de influência sobre os candidatos eleitos que tiveram suas campanhas financiadas por elas e que, logo, candidatos que recebem seu apoio acabam se comprometendo com elas, o que tem influenciado as políticas nacionais para o setor, como no caso das mudanças recentes do novo Código da Mineração.

O novo Código da Mineração surgiu a partir do Projeto de Lei (PL) 5.907/2013, encaminhado à Câmara dos Deputados pelo poder executivo. Para a apreciação do referido PL foi criada uma Comissão Especial nessa Câmara, da qual participaram como membros titulares 27 deputados federais. A pesquisa realizada por Oliveira (2014) demonstrou que um total de 20 desses 27 deputados receberam financiamento em suas campanhas de empresas mineradoras, o que denota

\footnotetext{
${ }^{8}$ O projeto de construção da UHE Tijuco Alto teve início no ano de 1988 e foi indeferido pelo Instituto Brasileiro de Meio Ambiente (IBAMA) em 2016.
} 
a potencial influência que empresas ligadas ao setor da mineração podem exercer sobre o parlamento do país. Além do poder legislativo, Oliveira (2014) analisou ainda o financiamento de campanhas realizado por empresas minerárias a candidaturas para os cargos de presidente da república, de governador e de senador, para o que também encontrou como resultado uma expressiva participação dessas empresas nos montantes arrecadados nas campanhas de candidatos eleitos, de variados partidos políticos.

\section{e) Geração de impactos socioambientais}

Identificar os impactos socioambientais gerados pelas atividades ligadas à mineração não é uma tarefa fácil, visto que estes se apresentam em diferentes escalas espaciais e temporais e atingem de formas variadas ecossistemas e populações locais. Nesse sentido, Milanez (2017, p. 94) afirma que os "impactos socioambientais da mineração não são simples, nem espacialmente limitados, muito menos temporalmente restritos. Na verdade, muitos deles são ecologicamente complexos, espacialmente amplos e, por serem irreversíveis, temporalmente permanentes." Desse modo, buscamos apontar um panorama geral dos impactos socioambientais promovidos pelas atividades minerárias em Adrianópolis, cientes de que não esgotamos aqui esta tarefa.

Mesmo que tenha sido instalada há poucos anos no município, as atividades realizadas pela fábrica de cimento Supremo-Sécil em Adrianópolis têm promovido uma série de impactos socioambientais diretos já evidenciados, como, por exemplo: a poluição atmosférica, gerada pelas partículas em suspensão provenientes do transporte do minério de calcário, realizado por caminhões entre a mina que está sendo explorada e a fábrica; os danos causados à infraestrutura viária do município, por conta do intenso tráfego de caminhões, desencadeado pelas atividades de transporte de matéria prima e de cimento; o risco de acidentes de trânsito, devido a este tráfego intenso; as ameaças ao ecossistema local, principalmente àquele associado ao Rio Ribeira de Iguape e um de seus afluentes, no entorno dos quais localizam-se as instalações da fábrica; e danos à infraestrutura de residências de moradores locais, devido ao impacto causado por explosões realizadas nas minas para a extração do minério.

Além disso, novos danos poderão vir a ser causados em breve no local, somando-se aos anteriores, tendo em vista que a referida empresa possui um projeto de ampliação de suas instalações, para o qual estima a conclusão de execução até o final do ano de 2019. Este projeto conta com a previsão da instalação de um forno de coincineração de resíduos para produção de clínquer (matériaprima para a produção de cimento) e a realização de outras obras de infraestrutura, para as quais a empresa pretende investir cerca de R 113 milhões, segundo informações da Agência Estadual de 
Notícias (AEN, 2018). A perspectiva da empresa com a instalação do forno de coincineração é de realizar a queima de resíduos provenientes de Curitiba e, conforme consta no Relatório de Impacto Ambiental (RIMA) elaborado para o processo de licenciamento ambiental da instalação do forno, "preparar suas instalações para receber, acondicionar e alimentar o forno de clínquer com resíduos sólidos, líquidos e/ou pastosos de diversas naturezas, inclusive os perigosos" (SUPREMO-SECIL, 2017, p. 34).

De acordo com Milanez et al (2009, p. 2143), "a saúde dos trabalhadores e das pessoas que moram próximas às fábricas de cimento vem sendo prejudicada pela poluição emitida pelas empresas de cimento, em especial por aquelas que praticam a coincineração." Assim, as atividades da fábrica de cimento em Adrianópolis implicam também em ameaças socioambientais latentes ao ecossistema e às populações locais, as quais poderão se manifestar em impactos concretos em um futuro breve.

Além dos impactos manifestos ou latentes causados pelas atividades relacionadas à produção de cimento em Adrianópolis na atualidade, cabe ressaltar que a possibilidade da instalação de outras fábricas de cimento no município eleva significativamente a magnitude das ameaças socioambientais latentes, uma vez que os impactos provenientes de mais de um empreendimento deste porte na região tendem a implicar em efeitos sinérgicos ainda desconhecidos e, tampouco, avaliados nos EIA/RIMAs destes empreendimentos 9 .

Cabe apontar ainda que a existência de um número expressivo de processos minerários referentes a outras 15 substâncias minerais que no momento não têm sido exploradas no município revela mais um agravante em relação a outras ameaças socioambientais latentes que se apresentam no caso em tela. Nesse sentido, merece especial atenção o fato de que dentre os processos minerários ativos encontra-se um grande número referente a minerais metálicos, como o cobre, o zinco e o chumbo, sendo que os impactos socioambientais gerados a partir da realização de atividades ligadas à extração destes minérios, em geral, implicam em riscos mais acentuados para ecossistemas e populações locais.

\section{f) Aprofundamento de conflitos socioambientais}

As atividades ligadas à indústria da mineração em Adrianópolis também têm promovido o aprofundamento de conflitos socioambientais na região, que se dão, especialmente, entre comunidades de moradores locais e empreendimentos minerários. Adotamos aqui a definição de

\footnotetext{
${ }^{9}$ Em nenhum dos três EIA/RIMAs de fábricas de cimento previstas para serem instaladas em Adrianópolis (no caso da Margem/Supremo Sécil, já instalada) disponibilizados na página virtual do IAP (MARGEM, 2010, 2017; TUPI, 2012; GOLDEN MIX, 2014), há alguma menção sobre a possível ocorrência de impactos sinérgicos que poderão ser derivados da instalação de mais de uma fábrica deste tipo no município.
} 
conflitos socioambientais elaborada por Svampa (2013), quem os concebe como sendo:

(...) aquellos ligados al acceso y control de los bienes naturales y el territorio, que suponen, por parte de los actores enfrentados, intereses y valores divergentes en torno de ellos, en um contexto de gran asimetría de poder. Estos conflictos expresan diferentes concepciones sobre el territorio, la naturaleza y el ambiente, al tiempo que van estableciendo una disputa acerca de lo que se entiende por desarrollo $\mathrm{y}$, de manera más general, por democracia. (SVAMPA, 2013, pp. 39-40).

No que diz respeito às atividades ligadas à mineração e à população local no município de Adrianópolis, o cenário de conflitos socioambientais se explicita com maior evidência, ao menos, em duas situações. A primeira, que deriva dos impactos socioambientais mencionados acima, os quais já têm sido sentidos pelos moradores da região, diz respeito a tensões mais pontuais que vêm sendo geradas entre moradores locais e a fábrica de cimento. Nesse sentido, têm surgido reclamações principalmente por parte de pessoas que moram na região central do município devido à grande quantidade de partículas em suspensão geradas pelo pó de calcário proveniente do transporte do minério entre a mina, localizada na divisa de Adrianópolis com Ribeira (SP), e a fábrica, que fica na Vila Carumbé, trajeto que atravessa o centro do município. Além disso, há reclamações também sobre o risco de danos que podem ser causados à estrutura de residências situadas próximas à mina de onde é extraído o calcário para a produção de cimento na fábrica devido aos tremores causados com as explosões frequentes realizadas para a extração do minério.

A segunda situação que merece atenção especial é em relação ao potencial avanço de atividades minerárias sobre territórios quilombolas no município. As comunidades quilombolas localizadas em Adrianópolis vêm sendo ameaçadas pelo avanço de empreendimentos ligados à indústria da mineração na região, o que é evidenciado, por exemplo, pela existência de processos minerários ativos sobre três territórios quilombolas certificados pela FCP no município atualmente, conforme explicitado na Figura 1. 


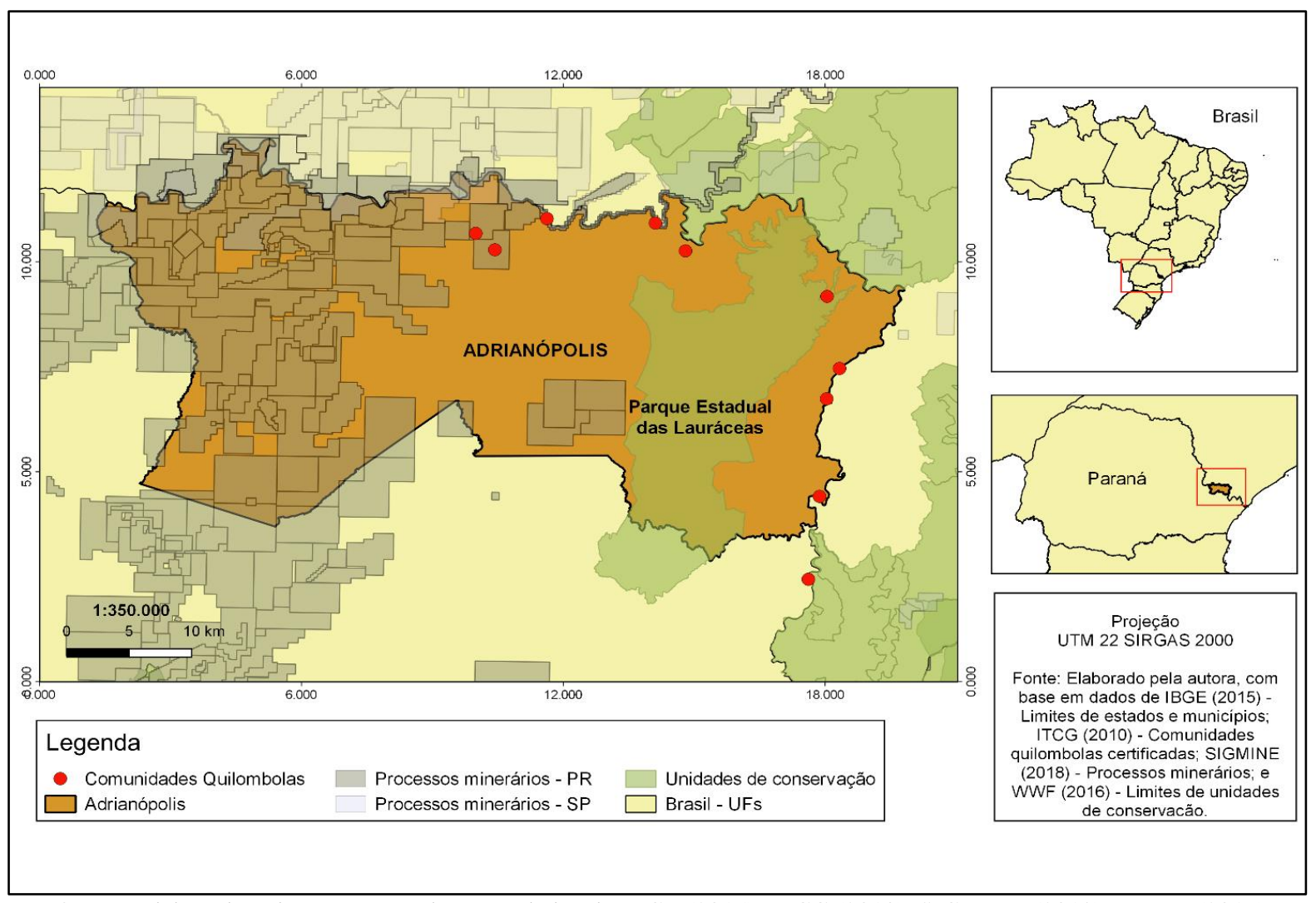

FONTE: Elaborado pela autora, com base em dados de IBGE (2015), ITCG (2010), SIGMINE (2018) e WWF (2016).

As três comunidades quilombolas sobre as quais se encontram concessões minerárias ativas são: Córrego das Moças, Sete Barras e Porto Velho. Cabe destacar que nenhuma delas passou pelo processo de consulta prévia, livre e informada sobre a concessão de áreas de exploração de minérios no interior de seus territórios, conforme recomendado pela Convenção 169 da Organização Internacional do Trabalho (OIT) sobre Povos Indígenas e Tribais, ratificada pelo Brasil em 2002 e promulgada por meio do Decreto 5.051 , de 19 de abril de $2004^{10}$. Além disso, o crescente número de processos minerários que tem ocorrido no município nos últimos anos aponta para a existência de uma ameaça latente sobre os demais territórios quilombolas de Adrianópolis sobre os quais tais processos ainda não se fazem presentes.

A territorialidade das comunidades quilombolas passa por um modo particular pelo qual se dá o uso e ocupação dos seus territórios, os quais têm seus limites reconhecidos socialmente pelo grupo e pelas comunidades vizinhas. Nesses territórios há a predominância de formas de uso comum

\footnotetext{
${ }^{10}$ Essa Convenção expressa em seu artigo 15 que: "Em caso de pertencer ao Estado a propriedade dos minérios ou dos recursos do subsolo, ou de ter direitos sobre outros recursos, existentes na terras, os governos deverão estabelecer ou manter procedimentos com vistas a consultar os povos interessados, a fim de se determinar se os interesses desses povos seriam prejudicados, e em que medida, antes de se empreender ou autorizar qualquer programa de prospecção ou exploração dos recursos existentes nas suas terras" (BRASIL, 2004).
} 
da terra, pautadas em vínculos de parentesco e vizinhança estabelecidos entre os membros dos grupos ao longo do tempo (ABA, 1994). As relações que esses grupos estabelecem com a natureza se dão segundo uma outra racionalidade, de acordo com as suas especificidades culturais, cujos bens naturais também se inscrevem em uma dinâmica de uso comum (ALMEIDA, 2004).

Assim, a lógica que se encontra inscrita nos processos de instalação e operação de empreendimentos neoextrativistas contrasta com a lógica tradicional de uso e ocupação territorial realizada ancestralmente pelas comunidades quilombolas. Tal contraste se explicita, fundamentalmente, na forma da propriedade privada da terra e demais bens naturais pela qual operam os empreendimentos, que promovem o cercamento de terras e a mercantilização da natureza, em contraponto às normas costumeiras de apossamento e uso comum das terras e bens naturais praticadas pelas comunidades quilombolas. Nesse sentido, ocorre uma sobreposição de dinâmicas do desenvolvimento capitalista às dinâmicas específicas dessas comunidades, o que ameaça a territorialidade e os modos de vida próprios desses grupos.

Entretanto, à medida que atividades ligadas ao setor da mineração avançam sobre territórios quilombolas em Adrianópolis, assim como no Vale do Ribeira de modo geral, verifica-se também o fortalecimento e a ampliação da luta contra empreendimentos de caráter neoextrativista na região, que incluem ainda, além de empresas mineradoras, a expansão de grandes monocultivos madeireiros de pinus e eucalipto e projetos de geração de energia hidrelétrica nos quais é prevista a construção de barragens no rio Ribeira. Nesse cenário, as comunidades têm se organizado e lutado em defesa de seus territórios tanto a partir de associações comunitárias como em conjunto com movimentos sociais diversos, como a Federação das Comunidades Quilombolas do Paraná (Fecoqui), o Movimento dos Ameaçados por Barragens (MOAB), a Equipe de Articulação e Assessoria às Comunidades Negras (EAACONE), o Movimento dos Atingidos por Barragens (MAB) e o Movimento pela Soberania Popular frente à Mineração (MAM), por exemplo.

As ameaças que avançam sobre os territórios quilombolas na região, incluindo aquelas que se apresentam na figura de empreendimentos minerários, têm sido denunciadas por essas organizações em diversos espaços de ação coletiva, como em manifestações, audiências públicas e encontros realizados pelas comunidades do Vale do Ribeira, nos quais comunidades quilombolas de Adrianópolis têm tido significativa participação.

Desse modo, é possível observar a materialidade local que assumem conflitos socioambientais originados em escalas mais amplas e complexas da sociedade, que envolvem as dinâmicas econômicas e políticas que movem o setor da mineração em nível nacional e internacional. Expressões disso são evidenciadas, por exemplo, no avanço dos processos minerários sobre territórios 
quilombolas e nas mudanças ocorridas no Código da Mineração, ambos processos que têm sido promovidos sem consulta a essas populações e, tampouco, considerando suas especificidades socioculturais e territoriais, o que denota a existência de uma sobreposição de interesses econômicos e políticos sobre os direitos das comunidades quilombolas.

\section{Considerações finais}

Ao longo do texto apresentamos a configuração atual que tomam as atividades minerárias no município de Adrianópolis, explicitando as principais expressões neoextrativistas que estas atividades apresentam localmente. Em linhas gerais, evidenciamos fundamentalmente de que modo dinâmicas econômicas e políticas que operam em escalas mais amplas da sociedade exercem influências sobre as atividades minerárias realizadas no município bem como sobre os territórios e as populações locais.

Ainda que a extração de minérios efetivamente realizada em Adrianópolis na atualidade se concentre principalmente no calcário, direcionado à produção de cimento, o expressivo número de concessões minerárias ativas referentes a vários outros tipos de minérios aponta para um cenário futuro de possível expansão das atividades minerárias no município dentro dos próximos anos. Nesse contexto, evidencia-se a possibilidade do retorno da exploração de minerais metálicos, como o chumbo, o zinco e o cobre, por exemplo, o que não é realizado na região desde o ano de 1995, quando a empresa Plumbum encerrou suas atividades por conta do elevado grau de impactos socioambientais gerados. Assim, a possível expansão das atividades minerárias no município aponta não somente para o provável correlato aprofundamento dos impactos e conflitos socioambientais existentes como também para a possibilidade da emergência de novas formas de impactos e conflitos socioambientais que podem ser gerados com a extração de outros tipos de minérios, os quais ainda são desconhecidos.

Por mais que atualmente não esteja sendo realizada a exportação de minérios explorados em Adrianópolis, os resultados deste estudo indicam que, em alguma medida, as atividades minerárias realizadas no município inserem-se em uma dinâmica de subordinação ao mercado internacional, o que se explicita, principalmente, no controle exercido por empresas estrangeiras sobre a exploração de minérios na região. Um caso emblemático, nesse sentido, se apresenta na figura da Supremo-Sécil, uma empresa pertencente a um grupo português que atualmente se configura como sendo a maior responsável pela exploração minerária no município. 
No caso analisado, a presença do Estado evidencia-se principalmente por meio de incentivos fiscais e de financiamento público oferecidos à instalação de empreendimentos minerários em Adrianópolis, realizados pelo governo estadual, bem como do apoio político a estes empreendimentos explicitado pelo poder público local. Entretanto, a partir da verificação da existência de relações entre empresas do setor da mineração e representantes políticos do município, observa-se que este apoio político pode ser intensificado na medida em que candidatos que tiveram suas campanhas eleitorais financiadas por empresas minerárias são eleitos.

Em relação ao financiamento de campanhas verificamos também que o caso de Adrianópolis apresenta dinâmica semelhante à observada em nível nacional, onde empresas minerárias têm efetuado doações a campanhas de candidatos de diferentes partidos, o que evidencia a intenção destas empresas na obtenção de apoio político de candidatos eleitos para a realização de suas atividades. A potencial influência exercida por empresas do setor da mineração sobre as dinâmicas políticas locais acaba provocando assim ameaças à própria democracia, uma vez que a eleição de candidatos passa também a contar com o peso dos financiamentos de campanha exercido por estas empresas. Desse modo, tanto as eleições como a atuação do poder público acabam sofrendo significativas influências do setor privado, neste caso representado pela indústria da mineração.

Ao realizarem o financiamento de campanhas eleitorais municipais, estas empresas acabam adquirindo um poder de negociação para a instalação, operação e ampliação de seus empreendimentos, o que lhes possibilita a obtenção de uma "licença social" para atuar, tendo em vista que representantes do poder público exercem influências sobre a opinião pública da população local sobre tais empreendimentos. Assim, o poder público também acaba contribuindo para promover a invisibilização de impactos e o silenciamento de conflitos socioambientais gerados pelos empreendimentos na região, o que coloca em risco os ecossistemas e as populações locais.

Evidenciamos ainda que as ameaças materiais e simbólicas que os empreendimentos neoextrativistas representam para os territórios e populações quilombolas locais vão além dos impactos socioambientais imediatos promovidos pela operação de extração e processamento de minérios. A lógica que se encontra inscrita nos processos de instalação e operação de empreendimentos neoextrativistas contrasta com as lógicas de uso e ocupação territorial realizadas ancestralmente pelas comunidades quilombolas. A relação com a natureza estabelecida por estes empreendimentos se dá a partir de uma racionalidade que traz como pressuposto a dominação, onde predomina a mercantilização dos bens naturais, em contraste com as formas de relação desenvolvidas pelas comunidades com seus territórios e a natureza. Neste sentido, se faz urgente atentar para o formato em que se reproduz o modelo neoextrativista em sentido amplo, onde dinâmicas globais do 
sistema capitalista caminham no sentido de impor às populações as suas próprias dinâmicas, em detrimento das formas locais de (re)produção da vida e dos modos de vida específicos do local.

Tendo em vista os apontamentos anteriores, concluímos que as atividades ligadas ao setor da mineração no município de Adrianópolis se configuram como componentes de um modelo neoextrativista mais amplo que vem sendo promovido na América Latina em anos recentes, como aquele exposto por Gudynas $(2014 ; 2012 ; 2011 ; 2009)$. Contudo, evidenciamos que as expressões neoextrativistas ligadas à indústria da mineração neste município apresentam particularidades relativas às especificidades próprias do contexto socioambiental e político-econômico da região que as singularizam no interior do modelo mais amplo.

\section{Referências}

ACOSTA, A. Extrativismo e neoextrativismo: duas faces da mesma maldição. DILGER, G.; LANG, M.; PEREIRA FILHO, J. (Org.). Descolonizar o imaginário: debates sobre pós-extrativismo e alternativas ao desenvolvimento. São Paulo: Fundação Rosa Luxemburgo/Editora Elefante, 2016.

ASSOCIAÇÃO BRASILEIRA DE ANTROPOLOGIA (ABA). Documento do Grupo de Trabalho sobre as Comunidades Negras Rurais. Boletim informativo NUER, n. 1, 1994.

ALMEIDA, A. W. B. de. Terras tradicionalmente ocupadas: processos de territorialização e movimentos sociais. Revista Brasileira de Estudos Urbanos e Regionais, v. 6, n. 1, mai. 2004.

AGÊNCIA NACIONAL DE MINERAÇÃO (ANM). Processos minerários. Disponível em: < https://sistemas.dnpm.gov.br/SCM/Extra/site/admin/dadosProcesso.aspx >. Acesso: 18 abr. 2018.

Arrecadação CFEM. Disponível em:

<https://sistemas.dnpm.gov.br/arrecadacao/extra/Relatorios/arrecadacao_cfem.aspx>. Acesso: 18 abr. 2018.

BRASIL. Lei $n^{\circ}$ 13.575, de 26 de dezembro de 2017. Cria a Agência Nacional de Mineração e dá outras providências. Presidência da República Federativa do Brasil, Poder Executivo, Brasília, DF, 26 dez. 2017.

. Lei $\mathrm{n}^{\circ} 12.858$, de 9 de setembro de 2013. Dispõe sobre a destinação para as áreas de educação e saúde de parcela da participação no resultado ou da compensação financeira pela exploração de petróleo e gás natural e dá outras providências. Diário Oficial da União, Seção 1, 10 set. 2013, p. 1.

. Decreto $\mathrm{n}^{\circ}$ 5.051, de 19 de abril de 2004. Promulga a Convenção 169 da Organização Internacional do Trabalho (OIT) sobre Povos Indígenas e Tribais. Presidência da República Federativa do Brasil, Poder Executivo, Brasília, DF, 19 abr. 2004. 
BREMBATTI, K. Adrianópolis terá um futuro concreto. Gazeta do Povo, 06 abr. 2014. Disponível em: < http://www.gazetadopovo.com.br/vida-e-cidadania/adrianopolis-tera-um-futuro-concreto8q1gsvgvzaipfoh3sltz13zgu>. Acesso: 19 dez. 2017.

CIMENTEIRA vai investir mais R \$ 113 milhões na fábrica de Adrianópolis. Agência Estadual de Notícias (AEN), 042017.2 dez. Disponível <http://www.aen.pr.gov.br/modules/noticias/article.php?storyid=96524>. Acesso: 01 mar. 2018.

CIMENTO.ORG. Cimento no Brasil. Disponível em: <https://cimento.org/cimento-no-brasil/>. Acesso: 10 de set. 2018.

COELHO, T. P.; KATO, L. Extrativismo. In: GOMIDE, Caroline Siqueira; COELHO, Tadzio Peters; TROCATE, Charles; MILANEZ, Bruno; WANDERLEY, Luiz Jardim de Morais (Org.). Dicionário crítico da mineração. Marabá, PA: Editora Iguana, 2018.

CUNHA, F. G.; FIGUEIREDO, B. R.; PAOLIELLO, M. M. B.; CAPITANI, E. M. de. Diagnóstico ambiental e de saúde humana: contaminação por chumbo em Adrianópolis, no Estado do Paraná, Brasil. Geologia médica no Brasil, CPRM-Serviço Geológico do Brasil, ed. 1, v. 1, 2006, pp. 97103.

DEAN, W. A ferro e fogo: a história e a devastação da Mata Atlântica brasileira. MOREIRA, C. K. [trad.]. São Paulo: Companhia das Letras, 1996.

FUNDAÇÃO CULTURAL PALMARES (FCP). Certidões expedidas às Comunidades Remanescentes de Quilombos (CRQs) atualizada até a portaria $n^{\circ} 34 / 2019$, publicada no DOU de 18/02/2019. Disponível em: <http://www.palmares.gov.br/?page_id=37551>. Acesso: 02 mar. 2019.

GOLDEN MIX. Relatório de impacto ambiental: complexo minero industrial. Vol. único. Adrianópolis, mai. 2014. Disponível em: < http://www.iap.pr.gov.br/arquivos/File/2013__EIA_RIMA/Complexo_Minero_Industrial/RIMA/RIMA_Tupi.pdf>. Acesso: 20 mar. 2018.

GONÇALVES, R. J. de A. F. Capitalismo extrativista na América Latina e as contradições da mineração em grande escala no Brasil. Cadernos Prolam/USP, v. 15, n. 29, p. 38-55, jul./dez. 2016.

GONÇALVES, R. J. de A. F.; MILANEZ, B.; WANDERLEY, L. J. Neoextrativismo liberalconservador: a política mineral e a questão agrária no governo Temer. Revista Okara: Geografia em debate, v. 12, n. 2, p. 348-395, 2018.

GOVERNO do Paraná apoia a criação de agência no Vale do Ribeira. Agência Estadual de Notícias, 20 mai. 2014. Disponível em: <http://www.aen.pr.gov.br/modules/galeria/detalhe.php?evento=39866>. Acesso: 23 nov. 2017.

GOVERNO negocia investimentos de R \$ 12 bilhões com Paraná Competitivo. Agência Estadual de Notícias, 14 ago. 2011. Disponível em: <www.aen.pr.gov.br>. Acesso: 01 mar. 2018.

GUDYNAS, E. Conflictos y extractivismos: conceptos, contenidos y dinamicas. CochabambaBolívia: CESU, Universidad Mayor San Simón. Decursos Revista en Ciencias Sociales, n. 27-28, 2014, pp. 79-115. 
Estado compensador y nuevos extractivismos: las ambivalencias del progresismo sudamericano. Nueva Sociedad, n. 237, enero-feb. 2012. pp. 128-146.

. El nuevo extractivismo progresista en América del Sur: tesis sobre un viejo problema bajo nuevas expresiones. In: varios autores. Colonialismos del siglo XXI: negocios extractivos y denfensa del territorio en América Latina. Barcelona (España): Icaria Editorial, 2011. pp. 75-92.

. Diez tesis urgentes sobre el nuevo extractivismo: contextos y demandas bajo el progresismo sudamericano actual. In: SCHULDT, J.; ACOSTA, A.; BARANDIARÁN, A.; BEBBINGTON, A.; FOLCHI, M.; ALAYZA, A.; GUDYNAS, E. (Org.). Extractivismo, politica y sociedad. Série: Cuadernos de capacitación. Quito-Equador: Centro Andino de acción popular - CAAP Equador y Centro de Ecologia Social Latinoamericana - CLAES, 2009.

INSTITUTO AMBIENTAL DO PARANÁ (IAP). Editais de EIA/RIMA, RAS e Audiências Públicas. Disponível em:

http://www.iap.pr.gov.br/modules/conteudo/conteudo.php?conteudo=772>. Acesso: 29 mar. 2018.

INSTITUTO BRASILEIRO DE GEOGRAFIA E ESTATÍSTICA (IBGE). Malhas digitais: Brasil e Paraná, 2015. Arquivo vetorial no formato shapefile, Sistema de referência SIRGAS 2000. Disponível em:

ftp://geoftp.ibge.gov.br/organizacao_do_territorio/malhas_territoriais/malhas_municipais/municipio _2015/ >. Acesso: 29 set. 2018.

Cidades: $\quad$ Adrianópolis. 2010. Disponível

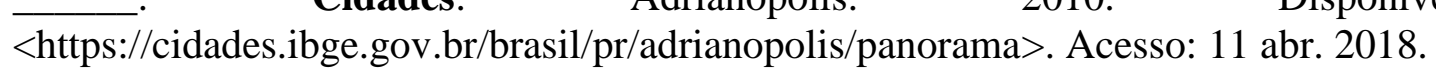

INSTITUTO BRASILEIRO DE MINERAÇÃO (IBRAM). Informações sobre a economia mineral brasileira 2015. RODRIGUES, C. de P.; COSTA, E. R. da. (Prod. Técnica). Relatório. Brasília, out. 2015. Disponível em: <www.ibram.org.br〉. Acesso: 11 abr. 2018.

INSTITUTO DE TERRAS, CARTOGRAFIA E GEOCIÊNCIAS (ITCG). Comunidades quilombolas no Paraná, 2010. Arquivo vetorial no formato shapefile, Sistema de referência SIRGAS 2000. Disponível em: http://www.itcg.pr.gov.br/modules/faq/category.php?categoryid=9\#>. Acesso: 16 out. 2016.

MARGEM COMPANHIA DE MINERAÇÃO. Relatório de impacto ambiental: unidade industrial para aglomerantes hidráulicos (cimento). Vol. 1, ed. 1. Adrianópolis, mar. 2010. Disponível em: < http://www.iap.pr.gov.br/arquivos/File/EIA_RIMA/FABRICA_CIMENTO_ADRIANOPOLIS/RI MA_MARGEM_Fabrica_Cimento_Adrianopolis_30032010.pdf>. /acesso: 22 mar. 2018.

MILANEZ, B. Mineração, ambiente e sociedade: impactos complexos e simplificação da legislação. Ipea: Boletim regional, urbano e ambiental. v. 16, jan.-jun. 2017. pp. 93-101.

MILANEZ, B.; SANTOS, R. S. P. dos. Neoextrativismo no Brasil? Uma análise da proposta do novo marco legal da mineração. Revista Pós em Ciências Sociais, v. 10, n. 19, jan.-jun. 2013. pp. 119148.

MILANEZ, B.; FERNANDES, L. de O.; PORTO, M. F. de S. A coincineração de resíduos em fornos de cimento: riscos para a saúde e para o meio ambiente. Ciência \& Saúde Coletiva, v. 14, ed. 6, 2009. pp. 2143-2152. 
MINERADORA que contaminou cidade de Caetano e Bethânia continua ativa. Carta Capital, 30 jan. 2012. Disponível em: <cwww.cartacapital.com.br/saúde/mineradora-que-contaminou-cidadede-caetano-e-bethania-continua-ativa/@ @amp>. Acesso: 21 de abril de 2018.

OLIVEIRA, C. R. Quem é quem nas discussões do novo Código da Mineração 2014. Comitê Nacional em Defesa dos Territórios Frente à Mineração, 2014. Cartilha.

RICHA ressalta impacto da nova cimenteira para o Vale do Ribeira. Casa Civil do Estado do Paraná, 17 de dez. 2015. Disponível em: <http://www.casacivil.pr.gov.br/2015/12/87292,10/Richaressalta-impacto-da-nova-cimenteira-para-o-Vale-do-Ribeira.html>. Acesso: 14 set. 2016.

SIGMINE. Processos minerários no Estado do Paraná, 2018. Arquivo vetorial no formato shapefile, Sistema de referência SIRGAS 2000. Disponível em: < http://sigmine.dnpm.gov.br/webmap/>. Acesso: 10 abr. 2018.

SILVA, R. H. P. da. Geoquímica e impacto ambiental do arsênio no Vale do Ribeira (SP-PR). Dissertação (Mestrado em Geociências) - Instituto de Geociências da Universidade Estadual de Campinas, Campinas, 1997.

SUPREMO-SECIL CIMENTOS. Relatório de Impacto Ambiental: coprocessamento de resíduos no forno de produção de clínquer. v. 1, ed. 1, mar. 2017. 49 p.

SVAMPA, M. <<Consenso de los commodities〉> y lenguajes de valoración en América Latina. Nueva Sociedad, n. 244, mar.-abr. 2013.

. Extractivismo neodesarrollista y movimientos sociales: ¿un giro ecoterritorial hacia nuevas alternativas? Grupo permanente de trabajo sobre alternativas ao desarrollo [org.]. Más allá del desarrollo. Ciudad de México: Ediciones Abya Yala/Fundación Rosa Luxemburg, 2012.

TRIBUNAL SUPERIOR ELEITORAL (TSE). Contas eleitorais: candidatos e comitês. Eleições de 2008 e 2012. Disponível em: <http://www.tse.jus.br/eleicoes/contas-eleitorais/candidatos-ecomites>. Acesso: 02 de ago. 2018.

TUPI MINERADORA. Relatório de impacto ambiental: complexo minero industrial. Vol. 1, ed. 1. Adrianópolis, dez. 2012. Disponível em: < http://www.iap.pr.gov.br/arquivos/File/2013__EIA_RIMA/Complexo_Minero_Industrial/RIMA/RIMA_Tupi.pdf>. Acesso: 20 mar. 2018.

WORLD WILDLIFE FUND (WWF). Unidades de Conservação no Brasil, 2016. Arquivo vetorial no formato shapefile, Sistema de referência SIRGAS 2000. Disponível em: < http://observatorio.wwf.org.br/uc/publico/mapa/>. Acesso: 10 mar. 2016.

Artigo recebido em 23/11/2018. Aceito para publicação em 26/04/2019. 